\title{
CHRONOLOGY OF LATE PLEISTOCENE HUMANS IN EURASIA: RESULTS AND PERSPECTIVES
}

\author{
Susan G Keates ${ }^{1}$ - Yaroslav V Kuzmin ${ }^{2}$ George S Burr 3,4 \\ ABSTRACT. A compilation of direct age determinations for Late Pleistocene human fossils in eastern Europe and Asia is \\ presented in this paper, and current problems with the dating of hominids in these regions are discussed. Only 25 human finds \\ (4 Neanderthals and 21 modern humans) have been directly dated from Pleistocene eastern Europe and Asia. Indirect dating \\ of human remains (using presumably associated organics) often is insecure, especially when information about the exact \\ provenance of human fossils is lacking. Continuation of direct dating of Late Pleistocene humans in Eurasia, primarily with \\ the help of the accelerator mass spectrometry (AMS) ${ }^{14} \mathrm{C}$ method, is therefore an urgent task.
}

\section{INTRODUCTION}

Prior to the 1990s, a few Pleistocene human fossils from Eurasia had been directly dated by radiometric methods. In the 1990s and 2000s, significant progress was achieved in the direct accelerator mass spectrometry (AMS) ${ }^{14} \mathrm{C}$ dating of Late Pleistocene humans from Europe and Siberia. This information can shed new light on the issues of the dispersal of anatomically modern humans and extinction of Neanderthals in the Old World. The results of direct AMS ${ }^{14} \mathrm{C}$ dating of some human bones (both Neanderthals and modern humans) in Europe and Asia were recently discussed (Pinhasi et al. 2011; Prat et al. 2011).

Direct dating of Pleistocene human bones using radiocarbon is being conducted mostly in western and central Europe (Richards et al. 2001; Schmitz et al. 2002; Svoboda et al. 2002; Trinkaus et al. 2003; Schulting et al. 2005; Wild et al. 2005; Higham et al. 2006a,b; Soficaru et al. 2006, 2007; Street et al. 2006; Jacobi and Higham 2008; Semal et al. 2009; Daura et al. 2010; Mannino et al. 2011; Wood et al. 2012). In eastern Europe and Asia, this practice is still rare (see Kuzmin 2009:158; Keates 2010).

It is now very clear that only the direct age determination of presumably Late Pleistocene human fossils can give us an understanding of their true antiquity. It was repeatedly demonstrated that human remains supposedly found in situ (e.g. Conard et al. 2004; Street et al. 2006) and some surface finds (e.g. Keates et al. 2007) are of a much younger age and therefore should be removed from the inventory of Pleistocene humans. This is especially important when the exact localization of the human fossil is uncertain, as it is quite frequently in some regions like China (see Keates 2010), or when we are dealing with surface finds (see Keates et al. 2007; Kuzmin et al. 2009). For example, direct AMS ${ }^{14} \mathrm{C}$ dating of the Wajak modern human femur from Java (Indonesia, Southeast Asia), previously believed to be of Late Pleistocene origin but whose stratigraphic position is unclear, produced an age of $6500 \pm 140 \mathrm{BP}$ (AA-7718) (Shutler et al. 2004).

In order to illustrate problems with radiometric ages obtained from different materials (charcoal, animal bones, flowstones, and other kinds) associated with human fossils, the recent case of Denisova Cave (Altai Mountains, Siberia) can be used. A human phalanx, with a genome different from

\footnotetext{
'Corresponding author. Email: archres2010@t-online.de.

${ }^{2}$ Institute of Geology \& Mineralogy, Siberian Branch of the Russian Academy of Sciences, Koptyug Ave. 3, Novosibirsk 630090, Russia.

${ }^{3}$ NSF-Arizona AMS Laboratory, University of Arizona, Tucson, Arizona 85721-0081, USA.

${ }^{4}$ Department of Geosciences, National Taiwan University, Taipei, Taiwan, Republic of China.
}

(c) 2012 by the Arizona Board of Regents on behalf of the University of Arizona Proceedings of the 6th International Radiocarbon and Archaeology Symposium, edited by E Boaretto and N R Rebollo Franco RADIOCARBON, Vol 54, Nr 3-4, 2012, p 339-350 
both Neanderthals and anatomically modern humans (tentative name of this hominid is Homo sapiens altaiensis, see Derevianko 2011:465), was apparently found in Layer 11.2 of the cave's Eastern Gallery in 2008 (Krause et al. 2010: Supplement, p 1; Reich et al. 2010: Supplement, p 85). At that time, only $2{ }^{14} \mathrm{C}$ dates were available and restricted to Layer 11 of the Southern Gallery of the cave, at 48,650 BP for Layer 11.2 and 29,200 BP for the top of the sequence, the contact of layers 10 and 11 (Derevianko 2010:9; Krause et al. 2010; Reich et al. 2010: Supplement, p 84). These values were used for the preliminary age estimate of the human bone (Krause et al. 2010:896). However, the ${ }^{14} \mathrm{C}$-dated stratum in the Southern Gallery is not stratigraphically connected with Layer 11 of the Eastern Gallery (see Reich et al. 2010: Supplement, p 84). Later on, several ${ }^{14} \mathrm{C}$ dates were generated from Layer 11 of the eastern and southern galleries (Reich et al. 2010:1059, Supplement, p 816). In the Eastern Gallery, the ${ }^{14} \mathrm{C}$ ages of human-modified animal bones vary from $\sim 15,740-23,170$ BP (Layer 11, without subdivision into sublayers; see Reich et al. 2010: Supplement, p 84) to $>50,000$ BP (Layer 11.3); and in the Southern Gallery, $2{ }^{14} \mathrm{C}$ dates on non-modified animal bones from Layer 11.2 are $>50,000 \mathrm{BP}$. It should be stressed again that these layers in the Eastern and Southern galleries are not stratigraphically connected; therefore, their numbers do not mean that they are contemporaneous (see Reich et al. 2010: Supplement, p 84). Unfortunately, it was not possible to date the human phalanx directly because of the small sample size (Reich et al. 2010: Supplement, $\mathrm{p}$ 84). Therefore, the wide range of ${ }^{14} \mathrm{C}$ dates from Layer 11 in both galleries of Denisova Cave limits our understanding of the age of the human fossils. It is suggested that the phalanx is derived from the undisturbed part of Layer 11.2 in the Eastern Gallery, but it is impossible to rule out the possibility of "major post-depositional mixing in this part of the cave" (Reich et al. 2010: Supplement, $\mathrm{p} 85$ ).

\section{METHODS AND MATERIAL}

Two radiometric methods, namely radiocarbon $\left({ }^{14} \mathrm{C}\right)$ and uranium-series (U-series), were used for direct dating of Pleistocene humans in eastern Europe and Asia. Following recent advances in ${ }^{14} \mathrm{C}$ dating of bone, including issues of collagen yield and ultrafiltration (see Brock et al. 2007, 2010a,b; Higham et al. 2006b; Hüls et al. 2007, 2009; Higham 2011; Talamo and Richards 2011), it was found that only bones with $1 \%$ or more of collagen are reliable in terms of their preservation, and ultrafiltration seems to be a preferable step in dating the older (i.e. more than $\sim 20,000-30,000 \mathrm{BP}$ ) specimens. Also, nowadays the measurement of yield, carbon and nitrogen stable isotope composition, and the $\mathrm{C}: \mathrm{N}$ ratio of extracted collagen is a must to understand the degree of collagen preservation. Samples with collagen yields $<1 \%$, and/or unusual $\mathrm{C}: \mathrm{N}$ ratios, beyond 2.9-3.6 as suggested by van Klinken (1999) and others (e.g. Brock et al. 2010a), should be rejected. Similarly, direct dates of Pleistocene humans reported without these parameters should be treated with extreme caution.

The reliability of U-series dating for Levantine fossil humans is hampered by the choice of the model of either early uptake (EU) or late uptake (LU) of uranium by bone (see e.g. Latham 2001:69; see also Pike and Pettitt 2003). Unfortunately, there is no comparative study for direct ages of human fossils from the Levant dated by both U-series and ${ }^{14} \mathrm{C}$ methods; at least we are not aware of it. In this case, particular care should be taken in the evaluation of $U$-series dates by means of comparison with the ${ }^{14} \mathrm{C}$ ages of the stratum from where human remains are recovered. As for the comparison of U-series dates with other chronometric methods (TL, ESR), information available from the Levant (e.g. Bar-Yosef 1994; Mercier and Valladas 1994; Schwarcz 1994) gives us several examples of large controversies such as with the Tabun and Skhul sites (see reviews: Pike and Pettitt 2003; Grün 2006:29-34). This most probably means that results of U-series dating of hominid fossils from Asia should be treated with some reservation, and independent evaluation of U-series ages should be conducted (e.g. Farrand 1994). 
Another warning about the reliability of direct U-series dating of human fossils comes from Japan where modern humans from Mikkabi (Honshu Island) were dated to $\sim 9100-20,900 \mathrm{yr}$ by Yokoyama (1992; cited by Matsu'ura and Kondo 2001:278; see also Keates 2010:457-8). Direct ${ }^{14} \mathrm{C}$ dating of the human bones gave much younger ages, 7450-9540 BP (Matsu'ura and Kondo 2001). Data on the physical anthropology of the Mikkabi human fossils indicated that they could be of Jomon age (Matsu'ura 1999:193; Ono et al. 1999:183), which ranges within $\sim 2500-12,500 \mathrm{BP}$, and ${ }^{14} \mathrm{C}$ dates confirmed this. However, the same suggestion for the Negata [Hamakita] humans (see Ono et al. 1999:183) turned out to be incorrect (see Table 1).

For this study, we assembled direct radiometric dates on human remains from eastern Europe (European Russia and Ukraine) and Asia available as of April 2012; they are arranged from west to east (Table 1; Figure 1). The results of direct dating of human fossils from the Ngandong and Sambungmacan sites (Java, Indonesia) show that samples dated by U-series underwent leaching of uranium (Yokoyama et al. 2008), which contradicts one of the basic assumptions of this method. This is why we did not include these ages in Table 1.

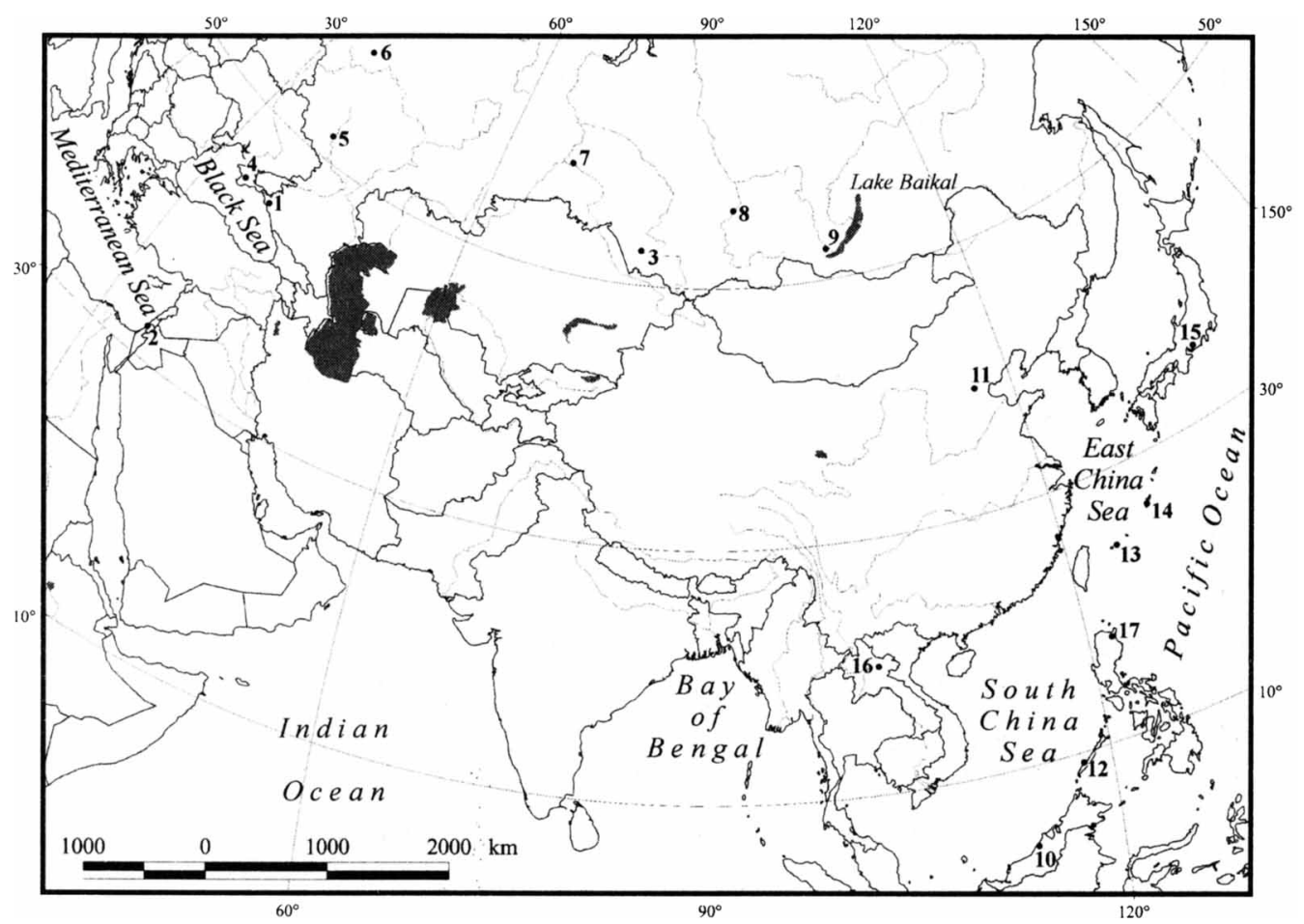

Figure 1 Location of fossil human finds in eastern Europe and Asia mentioned in the text. 1 - Mezmaiskaya Cave; 2 - Tabun Cave and Skhul Cave; 3 - Okladnikov Cave; 4 - Buran-Kaya III; 5 - Kostenki; 6 - Sungir; 7 - Baigara; 8 - Maly Log 2; 9 - Malta; 10 - Niah Cave; 11 - Tianyuan Cave; 12 - Tabon Cave; 13 - Shiraho-Saonetabaru Cave; 14 - Minatogawa; 15 Negata; 16 - Tam Hang Cave; 17 - Callao Cave.

In the following section, short comments are given about the direct ages of Late Pleistocene humans in eastern Europe and Asia whenever necessary. Recent discussions of direct dating of human fossils in western/central Europe can be found in Benazzi et al. (2011), Higham et al. (2011), Mellars (2011), and Prat et al. (2011). 


\section{RESULTS AND DISCUSSION}

\section{Neanderthals}

For the Mezmaiskaya Cave in the northern Caucasus, Russia (Figure 1), there is a large discrepancy between the ${ }^{14} \mathrm{C}$ ages of the Mez 1 and Mez 2 individuals (Table 1). The reason for this cannot be determined at present, but the value of $\sim 29,195 \mathrm{BP}$ for the Mez 1 individual was recently rejected due to inconsistency with other lines of evidence, including the lower stratigraphic position of Mez 1 (Layer 3) compared to Mez 2 (Layer 2) (see Pinhasi et al. 2011:8612). Thus, the minimal age for Neanderthals at Mezmaiskaya Cave (see Pinhasi et al. 2011:8615) is now considered to be $\sim 40,000$ cal BP (i.e. 34,800 BP; see Reimer et al. 2009).

At Tabun Cave in the Levant (Figure 1), the exact provenance of the Tabun $\mathrm{C} 1$ skeleton, which is directly dated by U-series, is unknown (Schwarcz et al. 1998). First direct age determinations of the Tabun C1 skeleton (Schwarcz et al. 1998) are contradictory and considered to be too young (Grün and Stringer 2000:610). The results of ESR dating of the Tabun C1 human fossils at 112,000 29,000 to $143,000 \pm 37,000 \mathrm{yr}$ (Grün and Stringer 2000) are much older than the U-series age of this sample at $\sim 47,000 \mathrm{yr}$ (see Table 1). In our opinion, the issue of this discrepancy has not been resolved. Comparisons of the human bone age with the chronology of the Tabun site were made (Grün and Stringer 2000; see also Grün et al. 1991), and it was suggested that the Tabun C1 individual comes from Layer B rather than from Layer C; the U-series date for Layer B is $\sim 90,000 \mathrm{yr}$ (Grün and Stringer 2000:610) as confirmed by Coppa et al. (2005; see also Table 1).

At Okladnikov Cave in Siberia, Russia (Figure 1), $3{ }^{14} \mathrm{C}$ values on the same material, a subadult humerus (see Krause et al. 2007: Supplement, p 2), received from 3 different laboratories, give a wide variation, from $\sim 37,800$ to $\sim 29,990 \mathrm{BP}$ (Table 1). The reason for this is unknown, and an average value of $34,190 \pm 760 \mathrm{BP}$ was suggested (Krause et al. 2007: Supplement, p 1). More recently, the value of $\sim 37,800 \mathrm{BP}$ was considered as the most reliable one (see Pinhasi et al. 2011:8614, Figure 3), although the reason for this is not indicated. The adult humerus from Okladnikov Cave, ${ }^{14} \mathrm{C}$ dated to $24,260 \pm 180 \mathrm{BP}$ (KIA-27010), cannot be attributed to a Neanderthal because of an absence of Neanderthal-like mtDNA primers (see Krause et al. 2007: Supplement, p 4), and its species determination is unclear (Krause et al. 2007:902).

\section{Modern Humans}

At the Kostenki 1 site in eastern Europe (Russia; Figure 1), dating was performed without (Richards et al. 2001) and with (Higham et al. 2006b) ultrafiltration, and no age difference is observed (Table 1). The standard deviation (sigma) for OxA-15055 value is much smaller than for the OxA-7073 one, and this is important in understanding the calendar age of the Kostenki 1 skeleton, because the calendar timespan for the OxA-15055 value is much shorter than for OxA-7073 (see Table 1). The age of the Kostenki 18 individual is much younger, $\sim 21,000 \mathrm{BP}$ (Table 1); due to the absence of a stratigraphic connection between these 2 directly dated humans, it is impossible to evaluate the age difference. The recently dated Kostenki 14 individual is the oldest at $\sim 33,250$ BP (Marom et al. 2012; see Table 1).

The situation at another Upper Paleolithic site in eastern Europe, Sungir [also Sunghir] (Russia; Figure 1), is still not clear; a definite difference is observed between the Tucson (lab code AA) and Oxford (lab code OxA) dates (Table 1), but currently there is no convincing clue as to what may have caused it (see Kuzmin et al. 2004). Redating of 2 skeletons from Sungir at the Leibniz AMS Laboratory in Kiel (Germany; lab code KIA) did not result in clarification of the age of the Sungir 1 individual (see Dobrovolskaya et al. 2012). There are now $3{ }^{14} \mathrm{C}$ values, $\sim 19,160 \mathrm{BP}, \sim 22,930 \mathrm{BP}$, 
and $\sim 27,050$ BP for Sungir 1 (Table 1). If we take into account the ${ }^{14} \mathrm{C}$ dates of $\sim 21,800-22,500 \mathrm{BP}$ run on charcoal collected beneath the Sungir 1 skeleton (see Kuzmin et al. 2004:733), the youngest value (AA-36473) is the most reliable one. As for the double burial of the Sungir 2 and 3 individuals, the new ${ }^{14} \mathrm{C}$ date of $\sim 26,000 \mathrm{BP}$ for Sungir 3 (Dobrovolskaya et al. 2012; Table 1) fits well with the existing Tucson dates of 26,200-27,050 BP (Sungir 2) and 26,190 BP (Sungir 3) (Table 1). The Oxford ${ }^{14} \mathrm{C}$ values on these 2 skeletons, produced after ultrafiltration of collagen, are younger: $\sim 24,800-25,400$ BP (Table 1).

The latest ${ }^{14} \mathrm{C}$ dates of the Sungir 2 and 3 individuals (Marom et al. 2012) are older than the other values (see Table 1). Although Marom et al. (2012) are convinced that the dating of hydroxyproline amino acid of collagen from these skeletons gives the most reliable ages, the situation, in our opinion, is not as simple as that. Without knowledge of the true age for the Sungir 2 and 3 burials, it is impossible to prove that some compounds in bone collagen are more resistant against contamination or degradation. Also, no one (to the best of our knowledge) was able to disprove scientifically the statement made by van Klinken (1999:690) that amino acid analysis tends "...to be relatively unhelpful for the assessment of 'collagen' quality."

In Siberia, the oldest human find so far is from Baigara in the central West Siberian Plain (Figure 1). The minimal calendar age of the human talus bone is 44,300 cal BP (Table 1). The "true" age could be even older if we take into account the geological data for this locality, which shows the existence of forests possibly dated to a relatively warm climate that began at 46,000 BP (see Kuzmin et al. 2009:93) or approximately 49,750 cal BP (see Reimer et al. 2009), but for this period there is no reliable calibration. Additional dating is needed to get a finite age, or at least to stretch it up to $\sim 49,900 \mathrm{BP}$ as this is the background for bone collagen at the Oxford AMS Lab (Wood et al. 2010).

More directly dated human fossils are known from insular East and Island Southeast Asia (Figure 1; Table 1). At the Niah Great Cave on Borneo [Kalimantan] Island, Malaysia, the first ${ }^{14} \mathrm{C}$ age of material associated with the "Deep Skull"-39,600 1000 BP (GRO 1339) (Harrisson 1958)-was later considered to be unreliable because of the uncertain association of the hominid and the dated samples (e.g. Brothwell 1960; Wolpoff 1999:735): "Moreover this 1958 radiocarbon date really means $>30 \mathrm{kyr}$, and may indicate no more than that there was insufficient carbon for an accurate age assessment" (Wolpoff 1999:735). Recently, a new dating program was set up (see Higham et al. 2009). The U-series date of $\sim 35,000 \mathrm{yr}$ on fragments of the "Deep Skull" (Barker et al. 2007; Table 1) is in agreement with the GRO 1339 value generated on charcoal collected near the skull during the excavation in the 1950 s and stored (see Harrisson 1958, 1959). The U-series date is also similar to the ${ }^{14} \mathrm{C}$ dates on charcoal and from the trench next to the "Deep Skull" spot dug in the course of the later opening: 35,690 $\pm 280 \mathrm{BP}(\mathrm{OxA}-\mathrm{V}-2076-16)$ and 35,000 $\pm 400 \mathrm{BP}$ (OxA-15126) (see Barker et al. 2007:252-4). A single direct ${ }^{14} \mathrm{C}$ date on Late Pleistocene human bone is known for mainland Southeast Asia at Tam Hang Cave in Laos, 15,740 \pm 80 BP (Demeter et al. 2009; no lab $\mathrm{nr}$ given).

In Tabon Cave on Palawan Island (the Philippines; Figure 1), the human fossils were initially correlated with ${ }^{14} \mathrm{C}$ dates of $\sim 22,000-24,000 \mathrm{BP}$ run on associated material (see Dizon et al. 2002:661), and a U-series direct dating gave an age of $\sim 16,500 \mathrm{yr}$ ago (Table 1). New discoveries of human bones allowed the continuation of the dating program (see Détroit et al. 2004); however, in this brief report no details on the stratigraphic position of the new finds are given, besides their depth in the profile for some of the human remains (Détroit et al. 2004:711). Instead, the authors refer to data such as "Square" and "S (surface)," presumably centimeters (?) below the cave's ground surface (?), and only 1 of the directly dated human bones is listed with the "S (surface)" data: Tibia fragment (IV-2000-T-197) at 16 [cm] (Détroit et al. 2004: Table 2). The new U-series dates are significantly 


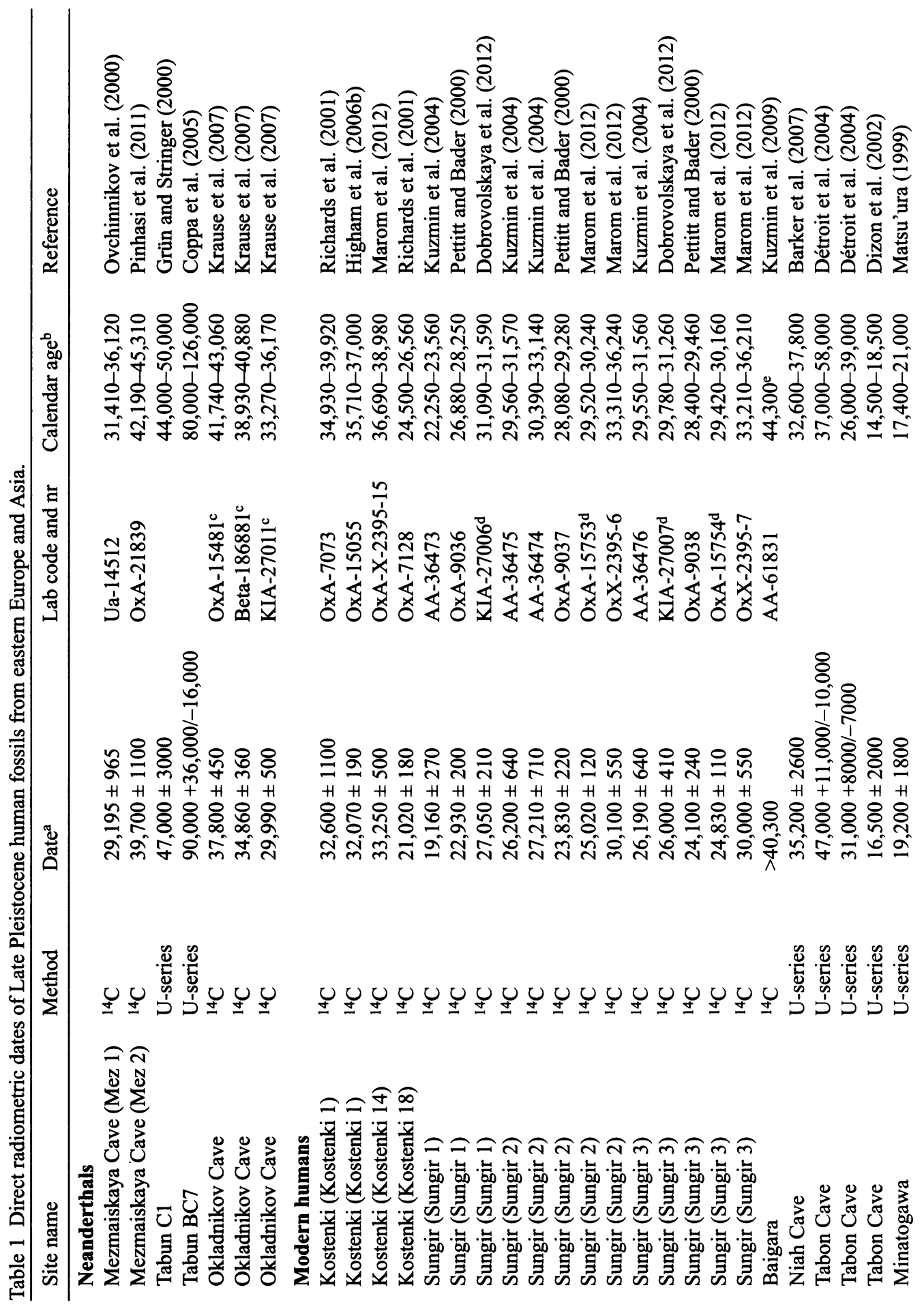




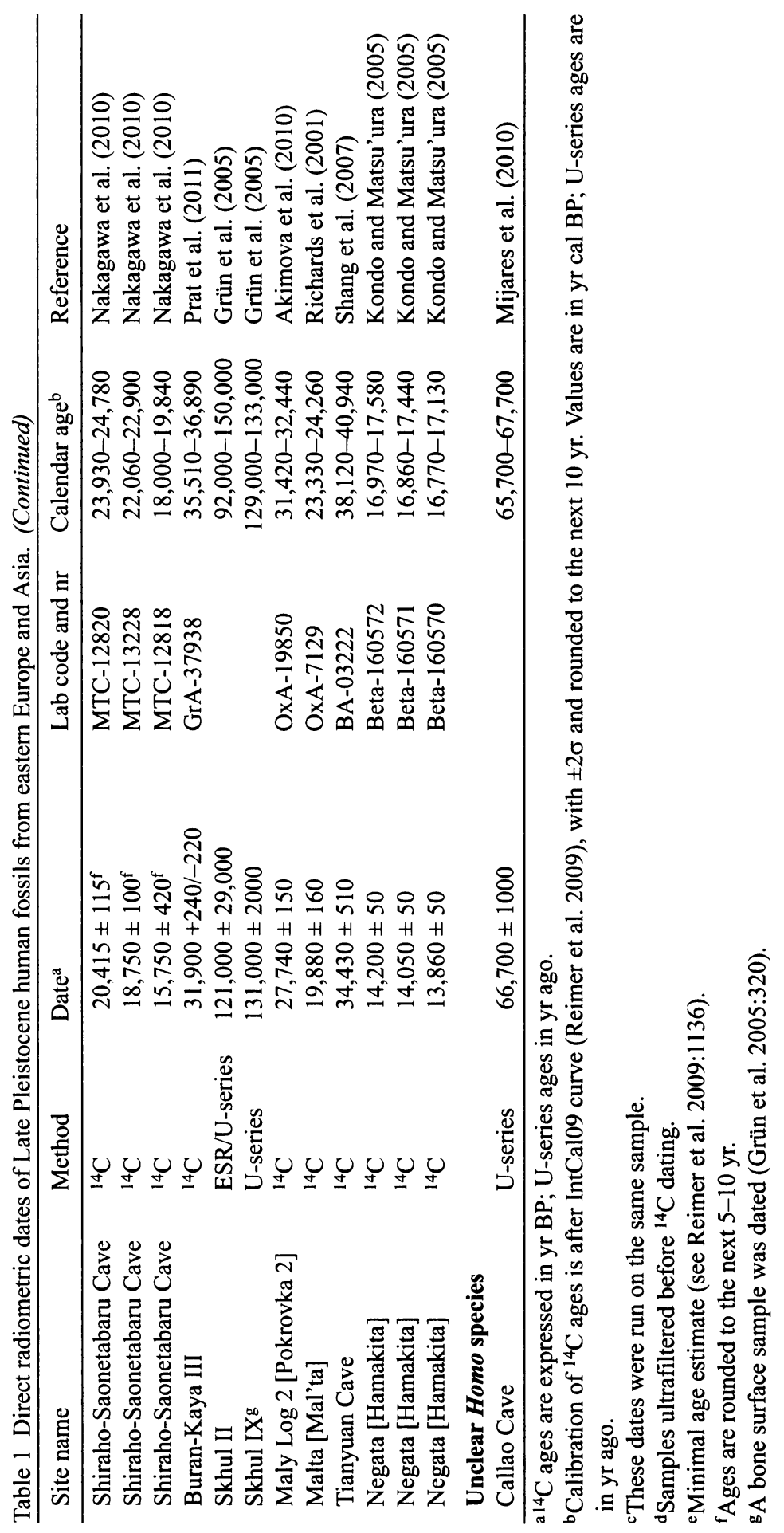


older than the one in Dizon et al. (2002) (see Table 1). Given that 1 of the charcoal ${ }^{14} \mathrm{C}$ dates from the early excavations is $\sim 30,100$ BP (see Dizon et al. 2002:660), and the fact that the sediment sequence at Tabon Cave is quite thick, at least $1 \mathrm{~m}$ (S G Keates and Y V Kuzmin, personal observation, 2006), this is not surprising. Judging from the current state of dating the human bones, one can suggest that several individuals (at least 3 ) have been recovered from Tabon Cave, and that they lived at quite different times within the $\sim 16,500-47,000 \mathrm{yr}$ timespan, while also noting the high deviations for the latter age (Détroit et al. 2004; Table 1). Unfortunately, it is not possible to evaluate the reliability of the age for humans at Tabon Cave due to insufficient information about the provenience of some directly dated samples (see Détroit et al. 2004:711); it was suggested that the older ages, $\sim 31,000-47,000 \mathrm{yr}$, fit better with the existing chronology of the cave (Détroit et al. 2004:710).

At the Minatogawa site (Ryukyu Islands, Japan; Figure 1), the U-series date of $\sim 19,200 \mathrm{yr}$ on a human cranium (Table 1) is scarcely known outside of Japan; see Matsu'ura (1999) who cited the original publication by Yokoyama (1992). This age is in accord with charcoal ${ }^{14} \mathrm{C}$ dates of $\sim 18,250$ 16,600 BP (see Keates 2010:455), corresponding to a calendar age range of 18,960-23,410 cal BP. However, Matsu'ura (1999:185) is not certain about the U-series age of the Minatogawa cranium because of possible leaching of uranium.

The first direct ${ }^{14} \mathrm{C}$ age of fossil humans from the Ryukyu Archipelago, which is located between mainland East Asia and the Japanese Islands, was only recently obtained for the Shiraho-Saonetabaru Cave (Nakagawa et al. 2010; Figure 1). Although an earlier age ( 32,000 BP and even older) was suggested for the Yamashita find from Okinawa Island (e.g. Trinkaus and Ruff 1996), which was never directly dated (see Keates $2010: 456$ ), the ${ }^{14} \mathrm{C}$ values from Shiraho-Saonetabaru Cave of $\sim 20,400-15,800$ BP (Table 1) make it possible to place the age of modern humans from the Ryukyus in a secure chronological context (Nakagawa et al. 2010). The investigation of this site is not yet finished and a new study will shed light on unresolved issues, such as for how long Paleolithic humans occupied the cave and how intensive their presence was during the Last Glacial Maximum, 26,500-19,000 cal BP (Clark et al. 2009).

As for the Skhul site in the Levant, the recent dating campaign brought consistent ESR/U-series and U-series ages for human remains of $\sim 121,000-131,000 \mathrm{yr}$ (Table 1), although the deviation for the $\sim 121,000 \mathrm{yr}$ date is high. The results of previous studies, which gave younger ages for this cave $\sim 32,000-100,000$ yr ago, are discussed in Grün (2006:31-6).

In terms of direct ages for other Pleistocene modern humans in eastern Europe and Asia, such as Buran-Kaya III, Maly Log 2, Malta, Tianyuan Cave, and Negata (see Table 1), they are in good agreement with other radiometric data $\left({ }^{14} \mathrm{C}\right.$ age of animal bones and other associated material) available for these localities, and can be accepted as secure dates.

\section{Uncertain Homo Species}

The recent discovery of human fossils in Callao Cave on Luzon Island (the Philippines; Figure 1) is the third only direct age determination for Pleistocene humans in the Southeast Asian region (see also Niah and Tabon caves), and this is why it is important for paleoanthropology and Paleolithic archaeology. The U-series age of a human metatarsal, $\sim 66,700 \mathrm{yr}$ (Table 1), is not consistent with another date of $\sim 52,000 \mathrm{yr}$ run on a cervid tooth from the same depth (Mijares et al. 2010:126), and the second cervid tooth age from $20 \mathrm{~cm}$ below the first tooth is $\sim 54,300 \mathrm{yr}$. This shows some disturbance of the stratigraphy in Callao Cave, as suggested by Mijares et al. (2010:126). Concerning the species determination of the Callao metatarsal, more research is needed to identify the species of this find (Mijares et al. 2010). 


\section{Asian Perspectives}

Several human fossils from East Asia could potentially be used for direct dating (see Keates 2010). However, due to different factors, including a reluctance to submit samples for destructive analysis and perhaps apprehension because of some potential age difference with a curators' a priori opinion (see e.g. Keates et al. 2007), the majority have not been dated yet. This to some extent limits the determination of the true age of Late Pleistocene humans in the region, and we can hope that in the near future the paradigm of some researchers will change, with evaluation of the age of human fossils on a scientific basis.

\section{CONCLUSION}

There are currently 4 directly dated Neanderthals and 21 modern humans from Pleistocene eastern Europe and Asia. The age of Neanderthals in eastern Europe and Asia, based on the most reliable evidence from the Mezmaiskaya and Okladnikov caves, is $40,000-34,000$ BP. Modern humans in eastern Europe are now dated to $232,000-33,000$ BP (Kostenki 1 and 14 and Buran-Kaya III); in Siberia up to $\sim 40,000 \mathrm{BP}$ and possibly older (Baigara); in East Asia to $234,000 \mathrm{BP}$ (Tianyuan Cave, China); and in Southeast Asia to 35,000 yr (Niah Cave) (i.e. 30,500 BP; see Reimer et al. 2009).

Indirect dating (using age determinations of presumably associated bones, charcoal, and other kinds of material) in many cases turned out to be quite unreliable, especially in situations where there is a lack of information about the exact provenance of human fossils or when these are surface finds. Thus, direct dating of Late Pleistocene humans, primarily with the help of the AMS ${ }^{14} \mathrm{C}$ method, is an urgent task.

\section{ACKNOWLEDGMENTS}

We are grateful to Dr Elisabetta Boaretto (Weizmann Institute of Science, Rehovot, Israel) for inviting us to participate in the 6th International Symposium "Radiocarbon and Archaeology" (Paphos, Cyprus, 10-14 April 2011). This study was supported by the Project "GIS Modeling and Spatial Analysis of Environmental Systems and Their Components" of the SB RAS Program IV.31.2; and by the Project "Problems of Desertification of Central Asia" of the RAS, Program 4.6. This paper is a revised version of our symposium poster presentation. We also thank Dr Pieter M Grootes (Leibniz Laboratory, Christian Albrechts University, Kiel, Germany) for useful comments and suggestions on the earlier version of this paper.

\section{REFERENCES}

Akimova E, Higham T, Stasyuk I, Buzhilova A, Dobrovolskaya M, Mednikova M. 2010. A new direct radiocarbon AMS date for an Upper Palaeolithic human bone from Siberia. Archaeometry 52(6):1122-30.

Barker G, Barton H, Bird M, Daly P, Datan I, Dykes A, Farr L, Gilbertson D, Harrisson B, Hunt C, Higham T, Kealhofer L, Krigbaum J, Lewis H, McLaren S, Paz V, Pike A, Piper P, Pyatt B, Rabett R, Reynolds T, Rose J, Rushworth G, Stephens M, Stringer C, Thompson J, Turney C. 2007. The 'human revolution' in lowland tropical Southeast Asia: the antiquity and behavior of anatomically modern humans at Niah Cave (Sarawak, Borneo). Journal of Human Evolution 52(3):243-61.

Bar-Yosef O. 1994. The contribution of Southwest Asia to the study of the origin of modern humans. In: Nitecki MH, Nitecki DV, editors. Origins of Anatomi- cally Modern Humans. New York: Plenum Press. p 23-66.

Benazzi S, Douka K, Fornai C, Bauer CC, Kullmer O, Svoboda J, Pap I, Mallegni F, Bayle P, Coquerelle M, Condemi S, Ronchitelli A, Harvati K, Weber GW. 2011. Early dispersal of modern humans in Europe and implications for Neanderthal behaviour. Nature 479(7374):525-9.

Brock F, Bronk Ramsey C, Higham T. 2007. Quality assurance of ultrafiltered bone dating. Radiocarbon 49(2):187-92.

Brock F, Higham T, Bronk Ramsey C. 2010a. Pre-screening techniques for identification of samples suitable for radiocarbon dating of poorly preserved bones. Journal of Archaeological Science 37(4):855-65.

Brock F, Higham T, Ditchfield P, Bronk Ramsey C. 
2010b. Current pretreatment methods for AMS radiocarbon dating at the Oxford Radiocarbon Accelerator Unit (ORAU). Radiocarbon 52(1):103-12.

Brothwell D. 1960. Upper Pleistocene human skull from Niah Caves, Sarawak. Sarawak Museum Journal 9: 323-49.

Clark PU, Dyke AS, Shakun JD, Carlson AE, Clark J, Wohlfarth B, Mitrovica JX, Hostetler SW, McCabe AM. 2009. The Last Glacial Maximum. Science 325(5941):710-4.

Conard NJ, Grootes PM, Smith FH. 2004. Unexpectedly recent dates for human remains from Vogelherd. $\mathrm{Na}$ ture 430(6996): 198-201.

Coppa A, Grün R, Stringer C, Eggins S, Vargiu R. 2005. Newly recognized Pleistocene human teeth from Tabun Cave, Israel. Journal of Human Evolution 49(3):301-15.

Daura J, Sanz M, Pike AWG, Subirà ME, Fornós JJ, Fullola JM, Julià R, Zilhão J. 2010. Stratigraphic context and direct dating of the Neandertal mandible from Cova del Gegant (Sitges, Barcelona). Journal of Human Evolution 59(1):109-22.

Demeter F, Sayavongkhamdy T, Patole-Edoumba E, Coupey A-S. 2009. Tam Hang rockshelter: preliminary study of a prehistoric site in northern Laos. Asian Perspectives 48(2):291-308.

Derevianko AP. 2010. Three scenarios of the Middle to Upper Paleolithic transition. Scenario 1: the Middle to Upper Paleolithic transition in Northern Asia. Archaeology, Ethnology \& Anthropology of Eurasia 38(3):232.

Derevianko AP. 2011. The Upper Paleolithic in Africa and Eurasia and the Origin of Anatomically Modern Humans. Novosibirsk: Institute of Archaeology and Ethnography Press. 560 p. In Russian and English.

Détroit F, Dizon E, Falguères C, Hameau S, Ronquillo W, Sémah F. 2004. Upper Pleistocene Homo sapiens from the Tabon cave (Palawan, the Philippines): description and dating of new discoveries. Comptes Rendus Paleovol 3(8):705-12.

Dizon E, Détroit F, Sémah F, Falguères $\mathrm{C}$, Hameau $\mathrm{S}$, Ronquillo W, Cabanis E. 2002. Notes on the morphology and age of the Tabon Cave fossil Homo sapiens. Current Anthropology 43(4):660-6.

Dobrovolskaya M, Richards MP, Trinkaus E. 2012. Direct radiocarbon dates for the mid Upper Paleolithic (eastern Gravettian) burials from Sunghir, Russia. Bulletins et Mémoires de la Société d'Anthropologie de Paris. doi: 10.1007/s13219-011-0044-4.

Farrand WR. 1994. Confrontation of geological stratigraphy and radiometric dates from Upper Pleistocene sites in the Levant. In: Bar-Yosef O, Kra RS, editors. Late Quaternary Chronology and Paleoclimates of the Eastern Mediterranean. Tucson: Radiocarbon. p 33-53.

Grün R. 2006. Direct dating of human fossils. Yearbook of Physical Anthropology 49:2-48.
Grün R, Stringer CB. 2000. Tabun revisited: revised ESR chronology and new ESR and U-series analyses of dental material from Tabun C1. Journal of Human Evolution 39(6):601-12.

Grün R, Stringer CB, Schwarcz H. 1991. ESR dating of teeth from Garrod's Tabun cave collection. Journal of Human Evolution 20(3):231-48.

Grün R, Stringer C, McDermott F, Nathan R, Porat N, Robertson S, Taylor L, Mortimer G, Eggins S, McCulloch M. 2005. U-series and ESR analyses of bones and teeth relating to the human burials from Skhul. Journal of Human Evolution 49(3):316-34.

Harrisson T. 1958. Carbon-14 dated palæoliths from Borneo. Nature 181(4611):792.

Harrisson T. 1959. Radiocarbon datings from Niah: a note. Sarawak Museum Journal 9:136-8.

Higham T. 2011. European Middle and Upper Palaeolithic radiocarbon dates are often older than they look: problems with previous dates and some remedies. Antiquity 85(327):235-49.

Higham T, Bronk Ramsey C, Karavani I, Smith FH, Trinkaus E. 2006a. Revised direct radiocarbon dating of the Vindija $\mathrm{G}_{1}$ Upper Paleolithic Neandertals. Proceedings of the National Academy of Sciences of the USA 103(3):553-7.

Higham TFG, Jacobi RM, Bronk Ramsey C. 2006b. AMS radiocarbon dating of ancient bone using ultrafiltration. Radiocarbon 48(2): 179-95.

Higham TFG, Barton H, Turney CSM, Barker G, Bronk Ramsey C, Brock F. 2009. Radiocarbon dating of charcoal from tropical sequences: results from the Niah Great Cave, Sarawak, and their broader implications. Journal of Quaternary Science 24(2): 189-97.

Higham T, Compton T, Stringer C, Jacobi R, Shapiro B, Trinkaus E, Chandler B, Gröning F, Collins C, Hillson S, O'Higgins P, FitzGerald C, Fagan M. 2011. The earliest evidence for anatomically modern humans in northwestern Europe. Nature 479(7374):521-4.

Hüls M, Grootes PM, Nadeau M-J. 2007. How clean is ultrafiltration cleaning of bone collagen? Radiocarbon 49(2):193-200.

Hüls M, Grootes PM, Nadeau M-J. 2009. Ultrafiltration: boon or bane? Radiocarbon 51(2):613-25.

Jacobi RM, Higham TFG. 2008. The "Red Lady" ages gracefully: new ultrafiltration AMS determinations from Paviland. Journal of Human Evolution 55(5): 898-907.

Keates SG. 2010. The chronology of Pleistocene modern humans in China, Korea, and Japan. Radiocarbon 52(2):428-65.

Keates SG, Hodgins GWL, Kuzmin YV, Orlova LA. 2007. First direct dating of a presumed Pleistocene hominid from China: AMS radiocarbon age of a femur from the Ordos Plateau. Journal of Human Evolution 53(1):1-5.

Kondo M, Matsu'ura S. 2005. Dating of the Hamakita human remains from Japan. Anthropological Science 
113(2):155-61.

Krause J, Orlando L, Serre D, Viola B, Prüfer K, Richards MP, Hublin J-J, Hänni C, Derevianko AP, Pääbo S. 2007. Neanderthals in central Asia and Siberia. $\mathrm{Na}$ ture 449(7164):902-4.

Krause J, Fu Q, Good GM, Viola B, Shunkov MV, Derevianko AP, Pääbo S. 2010. The complete mitochondrial DNA genome of an unknown hominin from southern Siberia. Nature 464(7290):894-7.

Kuzmin YV. 2009. Radiocarbon and Old World archaeology: shaping a chronological framework. Radiocarbon 51(1):149-72.

Kuzmin YV, Burr GS, Jull AJT, Sulerzhitsky LD. 2004. AMS ${ }^{14} \mathrm{C}$ age of the Upper Palaeolithic skeletons from Sungir site, Central Russian Plain. Nuclear Instruments and Methods in Physics Research B 223-224: $731-4$.

Kuzmin YV, Kosintsev PA, Razhev DI, Hodgins GWL. 2009. The oldest directly-dated human remains in Siberia: AMS ${ }^{14} \mathrm{C}$ age of talus bone from the Baigara locality, West Siberian Plain. Journal of Human Evolution 57(1):91-5.

Latham AG. 2001. Uranium-series dating. In: Brothwell DR, Pollard AM, editors. Handbook of Archaeological Sciences. Chichester: John Wiles \& Sons. p 63-72.

Mannino MA, Di Salvo R, Schimmenti V, Di Patti C, Incarbona A, Sineo L, Richards MP. 2011. Upper Palaeolithic hunter-gatherer subsistence in Mediterranean coastal environments: an isotopic study of the diets of the earliest directly-dated humans from Sicily. Journal of Archaeological Science 38(11):3094-100.

Marom A, McCullagh JSO, Higham TFG, Sinitsyn AA, Hedges REM. 2012. Single amino acid radiocarbon dating of Upper Paleolithic modern humans. Proceedings of the National Academy of Sciences of the USA 109(18):6878-81.

Matsu'ura S. 1999. A chronological review of Pleistocene human remains from the Japanese Archipelago. In: Omoto $\mathrm{K}$, editor. Interdisciplinary Perspectives on the Origins of the Japanese. Kyoto: International Research Center for Japanese Studies. p 181-96.

Matsu'ura S, Kondo M. 2001. Dating of the Mikkabi human remains from Japan. Anthropological Science 109(4):275-88.

Mellars P. 2011. The earliest modern humans in Europe. Nature 479(7374):483-5.

Mercier N, Valladas H. 1994. Thermoluminescence dates for the Paleolithic Levant. In: Bar-Yosef O, Kra RS, editors. Late Quaternary Chronology and Paleoclimates of the Eastern Mediterranean. Tucson: Radiocarbon. p 13-20.

Mijares AS, Détroit F, Piper P, Grün R, Bellwood P, Aubert M, Champion G, Cuevas N, De Leon A, Dizon E. 2010. New evidence for a 67,000 -year-old human presence at Callao Cave, Luzon, Philippines. Journal of Human Evolution 59(1):123-32.
Nakagawa R, Doi N, Nishioka Y, Nunami S, Yamauchi H, Fujita M, Yamazaki S, Yamamoto M, Katagiri C, Mukai H, Matsuzaki H, Gakuhari T, Takigami M, Yoneda M. 2010. Pleistocene human remains from Shiraho-Saonetabaru Cave on Ishigaki Island, Okinawa, Japan, and their radiocarbon dating. Anthropological Science 118(3):173-83.

Ono A, Oda S, Matsu'ura S. 1999. Palaeolithic cultures and Pleistocene hominids in the Japanese Islands: an overview. Daiyonki Kenkyu 38:177-83.

Ovchinnikov IV, Götherström A, Romanova GP, Kharitonov VM, Liden K, Goodwin W. 2000. Molecular analysis of Neanderthal DNA from the northern Caucasus. Nature 404(6777):490-3.

Pettitt PB, Bader NO. 2000. Direct AMS radiocarbon dates for the Sungir mid Upper Palaeolithic burials. Antiquity 74(284):269-70.

Pike AWG, Pettitt PB. 2003. U-series dating and human evolution. In: Bourdon B, Henderson GM, Lundstrom CC, Turner SP, editors. Uranium-Series Geochemistry. Reviews in Mineralogy and Geochemistry. Volume 52. Washington, DC: Mineralogical Society of America. p 607-30.

Pinhasi R, Higham TFG, Golovanova LV, Doronichev VB. 2011. Revised age of late Neanderthal occupation and the end of the Middle Paleolithic in the northern Caucasus. Proceedings of the National Academy of Sciences of the USA 108(21):8611-6.

Prat S, Péan SC, Crépin L, Drucker DG, Puaud SJ, Valladas $\mathrm{H}$, Lázniková-Galetová $\mathrm{M}$, van der Plicht $\mathrm{J}$, Yanevich A. 2011. The oldest anatomically modern humans from far southeast Europe: direct dating, culture and behavior. PLoS ONE 6(6):e20834.

Reich D, Green RE, Kircher M, Krause J, Patterson N, Durand EY, Viola B, Briggs AW, Stenze U, Johnson PLF, Maricic T, Good JM, Marques-Bonet T, Alkan C, Fu Q, Mallick S, Li H, Meyer M, Eichler EE, Stoneking M, Richards M, Talamo S, Shunkov MV, Derevianko AP, Hublin J-J, Kelso J, Slatkin M, Pääbo S. 2010. Genetic history of an archaic hominin group from Denisova Cave in Siberia. Nature 468(7327): 1053-60.

Reimer PJ, Baillie MGL, Bard E, Bayliss A, Beck JW, Blackwell PG, Bronk Ramsey C, Buck CE, Burr GS, Edwards RL, Friedrich M, Grootes PM, Guilderson TP, Hajdas I, Heaton TJ, Hogg AG, Hughen KA, Kaiser KF, Kromer B, McCormac FG, Manning SW, Reimer RW, Richards DA, Southon JR, Talamo S, Turney CSM, van der Plicht J, Weyhenmeyer CE. 2009. IntCal09 and Marine09 radiocarbon age calibration curves, 0-50,000 years cal BP. Radiocarbon 51(4): 1111-50.

Richards MP, Pettitt PB, Stiner MC, Trinkaus E. 2001. Stable isotope evidence for increasing dietary breadth in the European mid-Upper Paleolithic. Proceedings of the National Academy of Sciences of the USA 98(11):6528-32. 
Schmitz RW, Serre D, Bonani G, Feine S, Hillgruber F, Krainitzki H, Pääbo S, Smith FH. 2002. The Neandertal type site revisited: interdisciplinary investigations of skeletal remains from the Neander Valley, Germany. Proceedings of the National Academy of Sciences of the USA 99(20):13,342-7.

Schulting RJ, Trinkaus E, Higham T, Hedges R, Richards M, Cardy B. 2005. A mid-Upper Palaeolithic human humerus from Eel Point, South Wales, UK. Journal of Human Evolution 48(5):493-505.

Schwarcz HP. 1994. Chronology of modern humans in the Levant. In: Bar-Yosef O, Kra RS, editors. Late Quaternary Chronology and Paleoclimates of the Eastern Mediterranean. Tucson: Radiocarbon. p 21-31.

Schwarcz H, Simpson JJ, Stringer CB. 1998. Neanderthal skeleton from Tabun: U-series data by gamma-ray spectrometry. Journal of Human Evolution 35(6): 635-45.

Semal P, Rougier H, Crevecoeur I, Jungels C, Flas D, Hauzeur A, Maureille B, Germonpré M, Bocherens H, Pirson S, Cammaert L, De Clerck N, Hambucken A, Higham T, Toussaint M, van der Plicht J. 2009. New data on the late Neandertals: direct dating of the Belgian Spy fossils. American Journal of Physical Anthropology 138(4):421-8.

Shang H, Tong H, Zhang S, Chen F, Trinkaus E. 2007. An early modern human from Tianyuan Cave, Zhoukoudian, China. Proceedings of the National Academy of Sciences of the USA 104(16):6573-8.

Shutler Jr R, Head JM, Donahue DJ, Jull AJT, Barbetti MF, Matsu'ura S, De Vos J, Storm P. 2004. AMS radiocarbon dates on bone from cave sites in southeast Java, Indonesia, including Wajak. In: Keates SG, Pasveer JM, editors. Quaternary Research in Indonesia. Modern Quaternary Research in Southeast Asia 18. Leiden: A.A. Balkema Publishers. p 89-94.

Soficaru A, Doboş A, Trinkaus E. 2006. Early modern humans from the Peştera Muierii, Baia de Fier, Romania. Proceedings of the National Academy of Sciences of the USA 103(46):17,196-201.

Soficaru A, Petrea G, Doboş A, Trinkaus E. 2007. The human cranium from Peştera Cioclovina Uscată, Romania: context, age, taphonomy, morphology and paleopathology. Current Anthropology 48(4):611-9.
Street M, Terberger T, Orschiedt J. 2006. A critical review of the German Paleolithic hominin record. Journal of Human Evolution 51(6):551-79.

Svoboda J, van der Plicht J, Kuželka V. 2002. Upper Palaeolithic and Mesolithic human fossils from Moravia and Bohemia (Czech Republic): some new ${ }^{14} \mathrm{C}$ dates. Antiquity 76(294):957-62.

Talamo S, Richards M. 2011. A comparison of bone pretreatment methods for AMS dating of samples $>30,000$ BP. Radiocarbon 53(3):443-9.

Trinkaus E, Ruff CB. 1996. Early modern human remains from eastern Asia: the Yamashita-cho 1 immature postcrania. Journal of Human Evolution 30(4): 299-314.

Trinkaus E, Milota Ş, Rodrigo R, Mircea G, Moldovan O. 2003. Early modern human cranial remains from the Peştera cu Oase, Romania. Journal of Human Evolution 45(3):245-53.

van Klinken GJ. 1999. Bone collagen quality indicators for palaeodietary and radiocarbon measurements. Journal of Archaeological Science 26(6):687-95.

Wild EM, Teschler-Nicola M, Kutschera W, Steier P, Trinkaus E, Wanek W. 2005. Direct dating of early Upper Palaeolithic human remains from Mladeč. $\mathrm{Na}$ ture 435(7040):332-5.

Wolpoff MH. 1999. Paleoanthropology. 2nd edition. Boston: McGraw-Hill. 878 p.

Wood R, Bronk Ramsey C, Higham TFG. 2010. Refining background correction for radiocarbon dating of bone collagen at ORAU. Radiocarbon 52(2):600-11.

Wood RE, Higham TFG, De Torres T, Tisnérat-Laborde N, Valladas H, Ortiz JE, Lalueza-Fox C, SánchezMoral S, Cañaveras JC, Rosas A, Santamaría D, De La Rasilla M. 2012. A new date for the Neanderthals from El Sidrón Cave (Asturias, northern Spain). $A r$ chaeometry. doi: 10.1111/j.1475-4754.2012.00671.x.

Yokoyama Y. 1992. Gendai-jin no kigen wo saguru [Quest for the origins of modern humans]. Kagaku 62: 195-6. In Japanese.

Yokoyama Y, Falguères C, Sémah F, Jacob T, Grün R. 2008. Gamma-ray spectrometric dating of late Homo erectus from Ngandong and Sambungmacan, Central Java, Indonesia. Journal of Human Evolution 55(2): 274-7. 